\title{
Over-the-scope tissue retraction system (TRS)-facilitated endoscopic submucosal dissection of a large rectal polyp
}

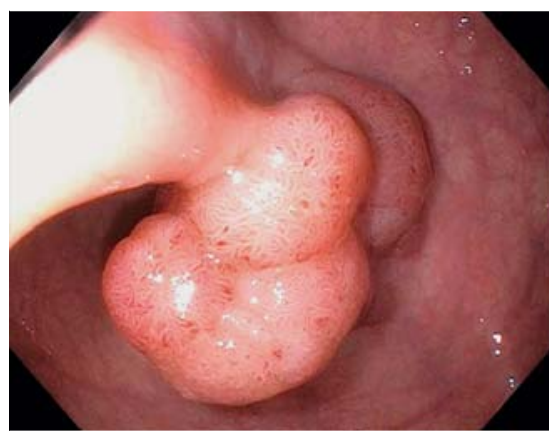

- Fig. 1 Endoscopic view of tubulovillous adenoma with high grade dysplasia, that had been noted at previous routine screening colonoscopy in a 52-year-old woman.

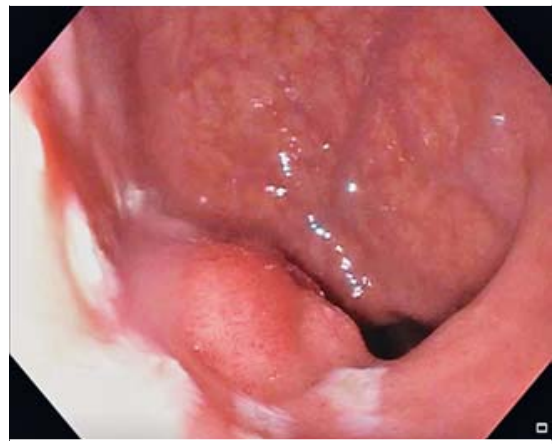

- Fig. 2 Endoscopic view of tubulovillous adenoma with marked margins.

A 50-year-old woman with no significant past medical history was referred to our clinic for evaluation and management of a large rectal tubulovillous adenoma with high grade dysplasia that had been noted on routine screening colonoscopy. Prior to therapy, staging was performed using endoscopic ultrasound. This revealed a $3-\mathrm{cm}$ lesion with a broad base overlying the first valve of Houston, approximately $5 \mathrm{~cm}$ from the anal verge ( Fig.1). Sonographically the lesion involved the mucosa and submucosa,

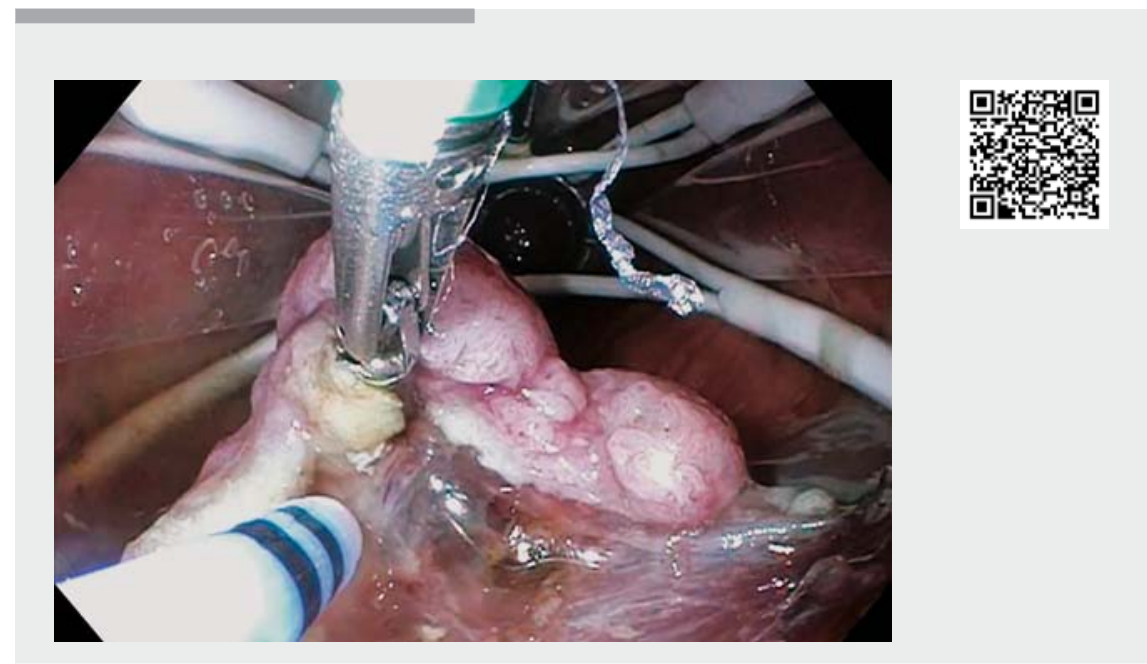

$\checkmark$ Video 1 Endoscopic submucosal dissection of tubulovillous adenoma facilitated by countertraction of the polyp using an over-the-scope tissue retraction system.

without deeper invasion. No regional lymphadenopathy was identified. The echoendoscope was then exchanged for a forward-viewing upper endoscope which was advanced to the site of the polyp. A multifunction electrosurgical knife with waterjet capability was used to expand the submucosal space and then to make a circumferential incision around the lesion into the submucosal space (-Fig.2). Subsequently an overthe-scope tissue retraction system (TRS) was inserted into the rectum and positioned over the lesion. The TRS device was used to provide countertraction on the polyp, facilitating endoscopic submucosal dissection. The polyp was then carefully resected en bloc from the submucosa and the defect closed with a single endoscopic suture ( $\vee$ Video 1 ).

Endoscopic submucosal dissection (ESD) using this novel over-the-scope TRS is a minimally invasive solution for management of superficial large benign and ma- lignant neoplasms of the rectum and distal colon. The TRS device improves visualization and creates countertraction on the lesion throughout the procedure, providing ease of submucosal dissection. This may confer a safer and faster overall procedure than conventional ESD.

Endoscopy_UCTN_Code_TTT_1AQ_2AC

\section{Competing interests}

P. Tarnasky is a consultant and speaker for Boston Scientific. P. Kedia is a consultant and speaker for Boston Scientific.

The authors

Rathan Reddy, Sheila Rastegari, Paul Tarnasky, Prashant Kedia

Methodist Dallas Medical Center, Dallas, Texas, USA 
Corresponding author

Rathan Reddy, MD

Gastroenterology, Methodist Dallas Medical Center, Graduate Medical Education, 1441 N. Beckley Ave, Dallas, Texas 75203-1201, USA

Fax: +1-214-947-6701

rathanreddy1982@gmail.com
Bibliography

DOI https://doi.org/10.1055/a-0991-7503

Published online: 17.9.2019

Endoscopy 2020; 52: E57-E58

(c) Georg Thieme Verlag KG

Stuttgart · New York

ISSN 0013-726X
ENDOSCOPY E-VIDEOS

https://eref.thieme.de/e-videos

回回 Endoscopy E-Videos is a free

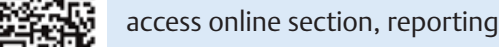
回: on interesting cases and new techniques in gastroenterological endoscopy. All papers include a high quality video and all contributions are freely accessible online.

This section has its own submission website at

https://mc.manuscriptcentral.com/e-videos 